\title{
Correction to: Fiscal Policy, Multidimensional Poverty, and Equity in Uganda: A Child-Lens Analysis
}

\author{
Jose Cuesta ${ }^{1}$ (D) Jon Jellema ${ }^{2} \cdot$ Lucia Ferrone $^{3}$
}

Published online: 30 September 2021

(C) The Author(s) 2021

\section{Correction to: The European Journal of Development Research (2021) 33:427-458 https://doi.org/10.1057/s41287-020-00283-y}

The article 'Fiscal Policy, Multidimensional Poverty, and Equity in Uganda: A Child-Lens Analysis', written by Jose Cuesta, Jon Jellema and Lucia Ferrone was originally published electronically on the publisher's internet portal on 18 of May 2021 without open access. With the author(s)' decision to opt for Open Choice the copyright of the article changed on 14 of September 2021 to $($ C The Author(s), 2021 and the article is forthwith distributed under a Creative Commons Attribution 4.0 International License, which permits use, sharing, adaptation, distribution and reproduction in any medium or format, as long as you give appropriate credit to the original author(s) and the source, provide a link to the Creative Commons licence, and indicate if changes were made. The images or other third party material in this article are included in the article's Creative Commons licence, unless indicated otherwise in a credit line to the material. If material is not included in the article's Creative Commons licence and your intended use is not permitted by statutory regulation or exceeds the permitted use, you will need to obtain permission directly from the copyright holder. To view a copy of this licence, visit http://creativecommons.org/ licenses/by/4.0.

The original article has been corrected.

The original article can be found online at https://doi.org/10.1057/s41287-020-00283-y.

Jose Cuesta

jcuesta@worldbank.org

1 World Bank, 1818 H Street NW, Washington, DC 20433, USA

2 Commitment to Equity Institute, Tulane University, 6823 St. Charles Ave. Tilton Hall, Suite 206, New Orleans, LA 70118, USA

3 Dipartimento di Scienze per l'Economia e l'Impresa, Via delle Pandette, 32, 50127 Florence, Italy 
Open Access This article is licensed under a Creative Commons Attribution 4.0 International License, which permits use, sharing, adaptation, distribution and reproduction in any medium or format, as long as you give appropriate credit to the original author(s) and the source, provide a link to the Creative Commons licence, and indicate if changes were made. The images or other third party material in this article are included in the article's Creative Commons licence, unless indicated otherwise in a credit line to the material. If material is not included in the article's Creative Commons licence and your intended use is not permitted by statutory regulation or exceeds the permitted use, you will need to obtain permission directly from the copyright holder. To view a copy of this licence, visit http://creativecommons.org/ licenses/by/4.0/.

Publisher's Note Springer Nature remains neutral with regard to jurisdictional claims in published maps and institutional affiliations. 